\title{
The Level of Audience Acceptance of Islamic Genre Films
}

\author{
Rosmawati Mohamad Rasit \\ Azimah Misrom \\ Salasiah Hanin Hamjah \\ Faculty of Islamic Studies, \\ Universiti Kebangsaan Malaysia, \\ Bangi, Selangor, Malaysia
}

DOI: https://doi.org/10.36941/ajis-202o-oo76

\begin{abstract}
The potrayal of religious elements in Islamic genre films have long been discussed among filmmakers. However, the audience acceptance is unclear and still at an infancy stage as the purpose of a film as a form of entertainment is predominant, which is contrary to the teachings of Islam. Thus, this study aimed to analyse the level of audience acceptance towards Islamic genre films. The design of this study was quantitative survey. Questionnaires were distributed to 500 respondents in five cinemas located in shopping malls in the Klang Valley area which were Alamanda, Mid Valley, The Mines, NU Central and KLCC. This study used purposive sampling, and data were analysed using descriptive statistics. The findings showed that the level of audience acceptance towards Islamic films is moderate with a mean value of 34.78 with a standard deviation of 4.38 .
\end{abstract}

Keywords: level of acceptance, audience, Islamic genre, film

\section{Introduction}

Today, the public has witnessed the production of various film genres due to the widespread of filmmaking knowledge besides the birth of many screenwriters, directors and producers. Marina Munira et al. (2011) suggested that due to natural human inclination towards venturing out into new territories, many art enthusiasts have produced captivating storylines as the selling point in publicising their works. Films are a common yet remarkable means in producing motion pictures and excellent storylines by turning on the characters, which then guarantee satisfaction in the audience (Jill 2007).

Naim (2011) stated that Islamic films are "halal" products that must be viewed holistically, starting from the pre-production to the viewing process. This implies that Islamic films should not be viewed from a limited perspective focusing solely on its content and artistic elements only. Further, films are capable of compelling the audience's interest and this in turn contributes to revenue gain for the film production. According to Mohd. Shukri (2012), producers must have the right knowledge in Islamic filmmaking. It is imperative for Muslim film producers, in particular, to portray an Islamic identity and lifestyle in the films they produce besides the entertainment value. Nevertheless, the questions on the extent of audience acceptance to Islamic genre films remains unadressed. Thus, 
this study aimed to analyse the level of audience acceptance of Islamic genre films.

$\mathrm{Ab}$ Samad and Daeng Haliza (2011) stated that the Malaysian film industry is gradually growing both in the quantity of film productions as well as the quality of high-tech film works. Furthermore, films are inseparable from the television or the cinema (Syed Mohd Zakir 2010). Greg (2011) stated that films and television programs offer plenty of excitement. On the other hand, according to Muammar Ghadafi (2008), film producers are more inclined towards presenting various societal elements in their films, which make such films popular among the audience. Meanwhile, Asiah and Nur Kareelawati (2008) stated that the number of local films for the cinema and television is steadily increasing; however, the integration of Islamic values within the films is still very low. The scenario poses concern over the film industry as filmmakers prefer producing films with genres that correspond merely with the audience's interest.

Apart from that, most of the storylines in films nowadays show less interest in the audience's well-being and provide more of what the audience wants instead. Fuziah Kartini (2015) explained that most of the television broadcasting stations in Malaysia operate based on niche audience concept which means that they serve a variety of programs according to specific segments. In response to the situation, Asiah (2015) suggested that the prolonged exposure to the culture within the liberalism concept, which serves as the globalisation reinforcement foundation has affected the Malaysian policymakers and the film media content industrial players. Therefore, it could trigger negative perception among the audience who watch this kind of programs and consequently, may cause them to lose interest in watching Islamic genre films. Subsequently, this may cause the filmmakers to refuse producing such films.

A study by Rosmawati et al. (2015) has established a link between watching films with Islamic elements with the audience's level of interest towards films with Islamic Islamic elements. Hence, the scenario provides an excellent opportunity for the local filmmakers to continue producing Islamic genre films because evidently, there is a high demand for this type of film genre among the audience. According to Juwairiah et al. (2015), creative presentations of a program content whether on the printed, electronic or new media will garner the audience's attention. Hence, the media should promote true Islamic values in a unique and creative style (Sharifah et al. 2015). Syed Zulkifli (2010) concurred that the production of decent films and television products containing Islamic values are capable of drawing the audience's interest and affecting them positively. Subsequently, this may lead to a positive acceptance towards Islamic genre films among y the audience. Therefore, this study aimed to analyse the level of audience acceptance of Islamic genre films.

\section{Literature Review}

The art of acting in the film industry is no longer a mere offshoot of arts and literature, but it has become a profitable industry and serves as the most effective propaganda tool around the globe (Maszlee 2007). Riber and Kelly (2014) suggested that actors enjoy their ability to influence the audience by playing and bringing a character to life. In filmmaking, this is pertinent as all elements must appear natural or realistic and not artifcial (Greg 1999). Furthermore, the society accepts films as a medium to recapture certain racial reality (Asiah 2009).

As for the actors, they would carefully consider a film genre before accepting a role to play. Meanwhile, for the film producers, they produce a variety of film genres for the audience, which will enable them to ascertain the genres that the audience is interested in for their next film production (Toby and Robert 1999). Film industry is also one of the avenues that contributes to the nation's economy. On the other hand, religious-related content has become one of the genres in films where filmmakers embed these divine elements within the film narrative (Teusner 2002).

The production of quality and decent films is critical in supporting nation building and progress. Most developed countries view the role of film making industry not only from the economic perspective but also in terms of the social development of their citizens focusing onthe adolescents who mostly keep up with the latest movie trends (Yunus 2011). Salsiah and Muhamad Kasim (2014) 
highlighted that films are a form of entertainment that has long existed in this country, which provide viewing pleasure for Malaysians. Therefore, films are indeed a form of entertainment which beauty lies in its ability to deliver messages of Islam to the audiencethus making them to be in close proximity with Allah SWT (Nur Hazriani 2017).

Further, Naim (2011) explained that a good storyline encompasses elements which are wellcrafted, particularly on the acting aspect. Actors are supposed to be capable of playing their ing roles effectively as they move, interact and perform according to the suitability of the actions and situations while at the same time maintaning the requirements of the script. Hence, in films production, filmmakers must further develop the character of religious teachers (ustaz) and preachers as one of the means to spread a better understanding of Islam (Shukri 2012). According to Dusuki (2011), films and dramas can be useful means to spark awareness and repentance. Today, undoubtedly, films and dramas serve as one of the significant tools to deliver messages of Islam and uphold its values. Hence, the use of films in delivering messages of Islam must be carefully and critically thought out to avoid confusions about Islam among the audience, even though fundamentally they are meant to carry the message of Islam (Rosmawati and Nur Hazriani 2018; Rosmawati and Azimah 2016).

Syed Zulkifli (2010) also stated that films and televisions are essential forms of media thus the Muslims must master the art of consuming them. Besides producing products with quality content, the integration of Islamic values within the products can attract the audience's interest and may indirectly affect them positively. This implies that films can have a powerful role in initiatingand spreading Islamic thoughts for them to become broader and more interactive (Syed Mohd Zakir 2010). Hence, the elements of Islam must be present in the film storyline because according to Fuziah Kartini et al. (2009), audience think that filmmakers must first pay attention to the content and message of a film. Further, Juwairiah et al. (2015) stated that creative presentations of a program content whether on the printed, electronic or new media will garner the audience's attention. Therefore, filmmakers should be conscientious before producing films infused with Islamic messages so that they will not confuse the audience on the message they are trying to relay (Nur Hazriani 2017). The audience will continue to be interested in Islamic genre films if the filmmakers produce creative and well-crafted ones while infusing the messages of Islamic for the viewing pleasure of the audience.

According to McQuail (1997), the audience refers to the readers, viewers and listeners of a channel or other media channels or of particular shows. Meanwhile, Rosmawati and Nur Hazriani (2018) suggested that the audience is a layer of a societal group that has a different thought, cultural and educational background besides having a unique view and definition of the movies they watch. Fuziah Kartini et al. (2009) stated that there are three groups of audience, which are the story audience, the entertainment audience, and the technical audience. However, presently, the young audience outnumbers the matured audience because they are more learned and critical in movie watching.

Siti Qoriatun Sholihah (2011) explained that a film has a high potential in influencing the audience's behaviour. It is because the strength and uniqueness of a film as media are so significant in psychologically influencing the audience. The actors achieve such effect when they put their best effort into playing a role in their distinctive way to influence the audience. A study by Tan (1994) explained that the act of watching films could influence the audience's emotion and can trigger the character's effects, which include empathy within the audience's self that is caused by the life experience that they had. A study by Rosmawati et al. (2015)established a link between the act of watching films containing the elements of Islam with the level of audience's interest in films infused with Islamic elements.

Theatrical films have a unique strength that psychologically can consume the mind and the feel of the audience especially the adolescents. Imagine the power to gather some adolescents in a particular space, and they are ready to be exposed to information; that is the advantage of the film that the Muslim filmmakers can use as a tool to persuade adolescents to the path of Islam (Asiah and Nur Kareelawati 2008). Supported by Naim (2010), he explained that a smart and disciplined 
audience surely would watch certain movies with specific motives that are usually inclined to goodness. The use of good viewing method will result in significant effects, and high level of viewing, among those, is the intention of viewing, the attempt to "read" the film viewed and viewing it in a room atmosphere with good ergonomic quality.

\section{Research Methodology}

This study used a quantitative method in addressing its objectives . The methodology employed was survey where 500 questionnaires were distributed to respondents in five cinemas located in shopping malls which were Mid Valley, Alamanda, The Mines, NU Sentral and KLCC. This study employed purposive sampling method in selecting the respondents. Data analysis was done using SPSS Version 25.0 software. Descriptive statistics was used in analysing the data, and the results were presented using frequency and percentage. The study also examined the data to determine the level of audience's acceptance to Islamic genre films.

\section{Findings and Discussion}

The findings show that there are three levels of audience acceptance towards Islamic genre films, which are low, moderate and high. Table 1 shows that the the level of audience acceptance to Islamic genre films is high with 37.2 per cent or 186 respondents.

Table 1: Level of Audience Acceptance of Islamic Genre Films

\begin{tabular}{lcc}
\hline Level & Frequency & Percentage (\%) \\
\hline Low (o-23) & 4 & 0.8 \\
Moderate (24-37) & 310 & 62.0 \\
High (38-50) & 186 & 37.2 \\
Mean: 34.78 & & Minimum: 10 \\
Standard Deviation: 4.38 & & Maximum: 50 \\
\hline
\end{tabular}

Audience should cultivate their interest in Islamic genre films. The purpose is, among others, to help increase the production of Islamic genre films. According to Naim (2011), there must be the act of encouraging righteousness and forbidding badness with an Islamic film. It is because films and dramas contain elements that can trigger awareness and penitence within the audience's inner self (Dusuki 2011). Moreover, Abd. Aziz (1997) explained that the portrayal of good examples of the everyday lives of a Muslim is an essential factor in expanding Islam besides brushing off the negative perception of the non-Muslims towards Islam.

Meanwhile, a study by Rosmawati (2013) found a link between the act of watching films containing the elements of Islam with the level of audience's interest in films infused with Islamic elements. In reality, there is a high demand from the audience for such films which provides an excellent opportunity for the local filmmakers to continue producing Islamic genre films. Besides enriching the local film industry with the talents and skills they have, the local Muslim filmmakers have also indirectly become a useful agent of Islam in spreading the message of Islam to a broader and more diverse mass audience. This is aligned with what Allah SWT said in Surah An-Nahl, verse 90:

Meaning: "Indeed, Allah orders justice and good conduct and giving to relatives and forbids immorality and bad conduct and oppression. He admonishes you that perhaps you will be reminded."

Meanwhile, the score for a moderate level of audience acceptance to Islamic genre films is at 62.0 per cent which is equivalent to 310 respondents. Following the viewing of specific films, the audience can explore them in several manners (Rosmawati and Nur Hazriani 2018). Due to different audience's interest in film genre, it is evident that there is a group of audience who is doubtful of the 
Islamic genre films. Therefore, according to Toby and Robert (1999), film producers should produce a variety of film genres for the audience to choose. Nonetheless, to a certain extent, this circumstance could affect the production of Islamic genre films if the audience views such films in a narrowminded perspective.

Teusner (2002) explained that by infusing the elements of God within a storyline of a film, it could also be considered as an Islamic film genre . Lately, there is a fascinating development in the local entertainment industryin which many producers are beginning to produce more spiritual infused films (Rozdan 2009). Alongside, the audience is also aware that the Islamic film genre has a particular impact on its audience, especially children. According to Naim (2011), films are food for the soul, feelings and thought. The craftsmanship of various forms of arts develops the specific perception that the audience feeds on and thus what is being fed to the audience must be right, pure, decent quality and permissible to be seen and to be "tasted" as the food serves for guests. It is supported by Munzier \& Harjani (2003) which stated that the storytelling of events that is rich in wisdom is an effective means to draw the attention of the target audience besides enriching the imagination of the past and also future. Furthermore, this could also be the best instrument that can be taken up by the Muslim missionaries (da'i) as it can penetrate deep into the audience's soul especially children.

Meanwhile, the score for the low audience acceptance to Islamic film genre was o.8 per cent, equivalent to 4 respondents. It shows that the level of the audience acceptance to Islamic genre films is low. The audience is not interested in Islamic-based films because most of the films especially the Malay ones are not Islamic in the first place. Syed Mohd Zakir (2010) suggested that most of the Malay films' narrative has long abandoned the tradition of the Malay culture as well as the Islamic practice with the emergence of indecent scenes such as free sex, drug abuse and life without God. In response to such situation, filmmakers should play a more active role in attracting the audience's interest in Islamic genre films. Moreover, it is not wrong to produce films that can gain audience's interest, but the filmmakers must craft them in a way that will not tamper the audience's thoughts by the narrowminded on-screen acting of the Islamic lifestyle.

According to Syed Zulkifli (2010), films and TV are crucial media and must be dominated by the Muslims to draw the audience's interest and produce a positive impact on them. Filmmakers must step up in increasing the audience's interest in Islamic genre films based on the moderate perception yielded from this study. This is due to the lack of understanding and knowledge of Islam among some film directors which does not allow them to use Islamic values in their products (Syed Mohd Zakir 2010). Further, Shukri (2012) suggested that in filmmaking, one of the ways to call people to a better direction in life is through the portrayal of a more developed role of a Muslim missionary. Hence, Zaynab (2008) stated that there are more constructive rooms for the Muslim film directors in producing Islamic genre films.

Overall, the level of audience acceptance to Islamic genre films shows a moderate level with the mean value of 34.78 and the standard deviation of 4.38. It signifies that Islamic genre films are is still not widely exposed to the local audience. The audience has different views about the Islamic genre films. Fuziah Kartini et al. (2009) argued that currently, the number of young audienceis far higher than the adult audience as they are more educated and critical when it comes to the viewing of films. It is also because they watch films for entertainment purposes as stated by Salasiah and \& Muhamad Kasim (2014) who claimed that films are an element of entertainment and that filmmakers have long produced films for the pleasure of watching. In conclusion, the level of audience acceptance of Islamic genre films is essential in measuring the extent of their acceptance to the Islamic genre films.

\section{Conclusions}

Muslim filmmakers should infuse the Islamic elements within the storyline of their films. It is to ensure that the concept can reach the audience via acting without scenes that can tarnish the image of Islam. In impacting the audience positively, films must include religious elements such as faith, 
laws, worship and morality. It is because each of the audience has a distinctive manner of acceptance in evaluating specific films. As for the industry, it must increase the volume of films that can positively impact the audience so that it corresponds with the expansion of Islamic within the society. Every layer of the society must seriously consider the production and the impact of films on the audience.

Hence, the Islamic genre films must be implemented in the production of a film to be aligned with the current Islamic expansion. A good film is one that has shariah compliant narrative and can positively impact as well as influence people.

\section{Acknowledgment}

Credit to The Ministry of Higher Education (MoHE) Malaysia and The National of University via the Fundamental Research Grant Scheme (FRGS). Project Code: FRGS/2/2013/SSIo3/UKM/o3/1

\section{References}

Ab. Aziz Mohd Zin. 1997. Pengantar Dakwah Islamiah. Kuala Lumpur: Penerbit Universiti Malaya.

Ab Samad Kechot dan Daeng Haliza Daeng Jamal. 2011. Non-Government Organisation (NGO) : Role NGOs Film in Malaysia for Literature. Journal of Techno-Social. Vol.3(1): 79-102.

Al-Quran

Asiah Sarji \& Nur Kareelawati. 2008. Filem Cereka Melayu Sebagai Salah satu Saluran Dakwah Remaja di Malaysia: Kajian Filem-Filem Arahan Pengarah-Pengarah Filem Muda Selepas Tahun 20oo. Paperwork of Dakwah and Media. Organized by Nadwa Islamiah Syeikh Abdullah al-Ghadamisi al-Magribi ke-2.

Asiah Sarji. 2009. Pembangunan Industri Perfileman Malaysia dalam Konteks Pendekatan Islam Hadhari. In . Mohd Safar Hasim dan Zulkiple Abd. Ghani (ed.). Komunikasi Di Malaysia Suatu Penelitian Awal Pendekatan Islam Hadhari, page.193-218. Bangi: Institut Islam Hadhari.

Asiah Sarji. 2015. Pembangunan Industri Perfileman Malaysia dalam Konteks Pendekatan Islam. In. Mohd Safar Hasim dan Zulkiple Abd. Ghani (pnyt.). Komunikasi \& Media dari Perspektif Islam: Konsep dan Amalan, page. 203-226.

Fuziah Kartini Hassan Basri, Faridah Ibrahim dan Mohd. Safar Hasim. 2009. Penontonan Filem Cereka di Malaysia: Tingkah Laku, Cita rasa, Persepsi dan Harapan. Kuala Lumpur: FINAS

Fuziah Kartini Hassan Basri. 2015. Televisyen dan Islam: Potensi dan Kekangan. In. Mohd Safar Hasim dan Zulkiple Abd. Ghani (pnyt.). Komunikasi \& Media dari Perspektif Islam: Konsep dan Amalan, page. 227-244.

Alterman, G.1999. Creating Your Own Monologue. New York : Allworth Press.

Dusuki Ahmad. 201. Menerapkan Nilai Agaman dan Keprihatianan Umat Dalam Filem dan Drama. In. Nor Hartini Saari. Edisi. Pemerkasaan Televisyen Dalam Mendidik Masyarakat, page. 69-8o. Kuala Lumpur: Penerbit Institut Kefahaman Islam Malaysia (IKIM).

Greg, W. 1999. Seeing and Being Seen: Distinctively Filmic and Religious Elements in Film. Journal of Religion and Film 3(2): 1-7.

Greg, M.S. 2011. What Media Classes Really Want to Discuss. New York: Routledge

H. Munzier Suparta \& Harjani Hefni. 2003. Metode Dakwah. Jakarta: Prenada Media

Jill, N. 2007. Introduction to Film Studie. Edisi ke-4. New York: Routledge Taylor \& Francis Group.

Juwairiah Hassan, Nor Raudah Hj. Siren dan Muhammed Yusof. 2015. Dakwah Melalui Tarikan Dalam Filem Dokumentari: Satu Tinjauan. Dlm. Yusmini Md Yusoff, Nor Raudah Hj Siren, Muhammed bin Yusof \& Fakhrul Adabi Abdul Kadir (pnyt.). Isu-isu Semasa Media dan Dakwah, page. 205-216. Kuala Lumpur: Universiti Malaya.

Marina Munira Mutalib, Suhailiza Md. Hamdani, Khatijah Othman, dan Roslizawati Mohd Ramli. 2011.Tugas dan Tanggungjawab Media Islam dalam Pembangunan Insan. In. Muhamad Zaki Mustafa, Ainurliza Mat Rahim, Zainol Abidin Ahmad dan Noor Adzrah Ramle (pnyt.). Representasi Islam dalam Media, page.49. Bandar Baru Nilai: Universiti Sains Islam Malaysia.

Maszlee Malik. 2007. Hukum Melakonkan Watak Nabi Mengikut Pandangan Islam. Access from http://www.mindaurus.blog.com/ [26 May 2009].

McQuail, D. 1997. Audience Analysis. London: SAGE Publications

Mohd. Shukri Hanapi. 2012. Penerbit Tiada Ilmu Buat Filem Islam. Harian Metro, 5 October : page. V4 \& V13. 
Muammar Ghadafi Hanafiah. 2008. Persepsi Remaja Melayu Islam Terhadap Pengaruh Filem Hiburan Luar di Rangkaian Televisyen Malaysia Ke Atas Pembangunan Sahsiah. Tesis Sarjana, UKM

Naim Hj. Ahmad. 2010. Filem Islam: Satu Perbicaraan. Kertas Kerja Bengkel Fiqh Penyiaran. Organized by JAKIM, TV Hijrah dan FDAM. ILIM, Bangi, 20 Jun

Naim Haji Ahmad. 2011. Filem Islam Satu Pembicaraan. Selangor: Uni-N Production Sdn. Bhd

Nur Hazriani Razali \& Rosmawati Mohamad Rasit. 2014. Filem Patuh Syariah Wasilah Dakwah Masa Kini. Dlm. Rosmawati Mohamad Rasit, Salasiah Hanin Hamjah \& Muhamad Faisal Ashaari (pnyt.). Dakwah, Media $\mathcal{E}$ Masyarakat, hlm. 109-119. Bangi: Jabatan Pengajian Dakwah dan Kepimpinan.

Nur Hazriani Razali. 2017. Kajian Fenomenologi Filem Patuh Syariah Sebagai Medium Dakwah Dalam Kalangan Audien Filem Di UKM. Tesis Sarjana, UKM.

Rieber, R.W \& Kelly, R. J. 2014. Film, Television and The Psychology of the Social Dream. London: Springer

Rosmawati Mohamad Rasit. 2013. Formation of the Pro-Social Behaviour among Adolescent Audience Through Exposure to Films. New Media and Mass Communication. Vol. 20: 21-28

Rosmawati Mohamad Rasit, Salasiah Hanin Hamjah, Siti Rugayah Tibek, Fariza Md. Sham, Muhammad Faisal Ashaari, Muhammad Adib Samsudin \& Adawiyah Ismail. 2015. Educating film audience through social cognitive theory reciprocal model. Procedia Social and Behavioral Sciences 174, 1234-1241.

Rosmawati Mohamad Rasit \& Azimah Misrom. 2016. Analisis Elemen Patuh Syariah dalam Filem Nur Kasih The Movie (2011) Berdasarkan Teori File ar-Risalah. Malaysian Journal of Communiction Vol. 32 No.1, 1-21.

Rosmawati Mohamad Rasit and Nur Hazriani Razali. 2018. Phemenological Study of Shariah-Compliant Films as Islamic Medium. Ulum Islamiyyah, Vol 23, 1-9.

Rozdan Mazalan. 2009. 2 Marhalah Santapan Jiwa. Berita Harian, 25 Mei .

Syed Mohd Zakir Syed Othman. 2010. Filem dan Pemikiran. Kuala Lumpur : Nusabuku Enterprise.

Salasiah Hanin Hamjah, Zainab Ismail, Fariza Md. Sham \& A'dawiyah Ismail. 2014. Ibadah Sebagai Faktor Motivasi Kerja Dalam Kalangan Pensyarah Fakulti Pengajian Islam, UKM. Dlm. Razaleigh Muhamat@Kawangit \& Inderis Endot (pnyt.). Pembangunan Dakwah Semasa, hlm. 109-118.

Siti Qoriatun Sholihah. 2011. Analisis Wacana Pesan Dakwah Film dalam Mihrab Cinta. Jakarta: Universitas Islam Negeri, Syarif Hidayatullah.

Syed Zulkifli Syed Masir. 2010. Melahirkan Strategi Kerja Kreatif Filem dan TV Pematuhan Syariah (Syariah Compliant). Paperwork for Bengkel Fiqh Penyiaran. Organized by JAKIM, TV Hijrah dan FDAM. ILIM, Bangi, 20 Jun

Tan, S.H. 1994. Film-Induced Affect As A Witness Emotion. Poetics 21(1994): 7-32

Teusner, P. 2002. Horror Film and the Construction of Religious Identity in Contemporary Media Culture. Pembentangan paaperwork for Qualifying Examination of the Master of Theology (Theol.M.). Melbourne College of Divinity, August 2002.

Toby, M. \& Robert, S. 1999. A Companion to Film Theory. Victoria: Blackwell Publishing.

Yunus Said. 2011. Peranan Televisyen dalam Memupuk Nilai Kemanusiaan Universal. In. Nor Hartini Saari. Edisi. Pemerkasaan Televisyen dalam Mendidik Masyarakat, page. 121-135. Kuala Lumpur: Penerbit Institut Kefahaman Islam Malaysia (IKIM).

Zaynab Herrera. 2008. Islam on Film: Discussion with a Muslim Film Director. Access from http://www.islamicinsights.com/news/community-affairs/islam-on-film-discussion-with-a-muslim-filmdirector.html [25 December 2014]. 